\title{
61. POLLEN ANALYSIS OF LAMINATED AND HOMOGENEOUS SEDIMENT FROM THE GUAYMAS BASIN, GULF OF CALIFORNIA ${ }^{1}$
}

\author{
Linda E. Heusser, Lamont-Doherty Geological Observatory, Columbia University, Palisades, New York
}

\section{INTRODUCTION}

Drilling at Site 480 , the first successful hydraulic piston coring of the Deep Sea Drilling Project, penetrated with little or no disturbance about 152 meters of varvelike sediments on the slope of the Guaymas Basin in the Gulf of California (Fig. 1). The Serocki-Storms-Cameron piston corer retrieved unusually large amounts of sediment containing potentially high-resolution data for multidisciplinary research (see site chapter, this volume, Pt. 1). The rhythmically laminated marine sediments of the Guaymas Basin are relatively rare, occurring where seasonal sediment flux is not destroyed or disturbed by infauna because of oxygen depletion of the bottom waters (Soutar, 1969; Calvert, 1964). Also preserved by the anoxic environment are the undisturbed records of annual variations in the greater biosphere of the Gulf of California, i.e., variations in marine and continental ecosystems inferred from the remains of such fossils as diatoms and pollen. This chapter presents, first, the initial results of pollen analyses from the first 87 samples available from Site 480 , representing a broad survey of all the cores from the site, and, second, pollen analysis of core samples, detailed analysis of $9 \mathrm{~m}$ of core, analyzed at 10-cm intervals, from 480-3-1 through 480-4-3.

\section{SETTING}

The Guaymas Basin is approximately in the middle of the Gulf of California, an elongate trough lying between peninsular Baja California, Mexico and the Mexican mainland (Fig. 1). An actively spreading oceanic basin over 2000 meters deep, the Guaymas Basin is distinguished by high sedimentation rates and by laminated diatomaceous ooze and mud, believed to represent annual varves (Shrader, this volume; van Andel and Shor, 1964). Muddy diatomaceous ooze is the result of prodigious diatom production and ample terrigenous contributions from the Rio Yaqui to the east; the varves result from the restriction of infauna by oxygen-depleted bottom waters (Calvert, 1964; van Andel, 1964).

The Río Yaqui (about $28^{\circ} \mathrm{N}$ latitude) is the southern boundary of the Sonoran Desert, a region lying principally below 1800 meters and bordered on the east by the relatively high, isolated peaks of the Sierra Madre Occidental. This subtropical desert is characterized by extremes of temperature and precipitation. Temperatures range from $1^{\circ} \mathrm{C}$ to over $40^{\circ} \mathrm{C}$. Although the bi-

\footnotetext{
${ }^{1}$ Curray, J. R., Moore, D. G., et al., Init. Repts, DSDP, 64: Washington (U.S. Govt, Printing Office).
}

modal rainfall annually varies from about 60 to 200 $\mathrm{mm}$, short, intense summer storms may account for over $150 \mathrm{~mm}$ locally (Burk, 1977; Cross et al., 1966). During the January-May dry season, winds are from the northwest (Roden, 1964). During the July-December rainy season, winds blow from the southeast over the Pacific coastal plain province where tropical lowland forests thrive under higher humidity and temperatures (Leopold, 1950).

The tropical and temperate vegetation zones surrounding the Gulf of California are arranged vertically along altitudinal moisture gradients (Leopold, 1950), although in the Sonoran, fire may also determine vegetational zonation. Most of the arid region around the Gulf is characterized by desert plant communities: creosote bush scrub, predominantly Larrea tridentata and Ambrosia dumosa, saltbush scrub with predominant Atriplex, and alkaline flat communities with Suaeda and other chenopods (Burk, 1977). Soil water availability and salt accumulation determine the distribution of the major species in desert communities. Creosote bush scrub occurs on sandy flats, bajadas, upland slopes, and along the margins of arroyos; it is probably the most widespread vegetation (Burk, 1979; Hevly et al., 1965). The density of creosote bush scrub decreases with increasing annual precipitation. With increasing salinity, saltbush scrub becomes more prominent. Species of Ephedra occur in saltbush and creosote bush scrub. Although California-type chaparral is not present in the watershed, various chaparral components occur frequently in Sonoran desert vegetation (Hastings et al., 1972). Mesquite grassland, a widely distributed temperate vegetation, mixes with desert communities along waterways and occurs in the Río Yaqui watershed (Leopold, 1950; Cross et al., 1966). Pine-oak (Pinus-Quercus) forest is present at higher elevations where precipitation increases to about 50 to $200 \mathrm{~cm}$ and varies from oak scrub on foothills bordering the desert to dense pine forests. Boreal forests of pine, fir (Abies), and alder (Alnus) are restricted to the relatively moist heights of the Sierra Madre Occidental.

Tropical forests (rain, tropical deciduous, and thorn), characterized by such plants as Bursera, Acacia, and Bombax, occur on the coastal plain, bajadas, and piedmont south of the Guaymas Basin (Leopold, 1950). Upslope, pine-oak forest is widely developed, as, for example, in the area north of the Guaymas Basin. Mangrove swamps, small but significant littoral communities of the southern Gulf coastal plain, extend north to about $40^{\circ} \mathrm{N}$ latitude. 


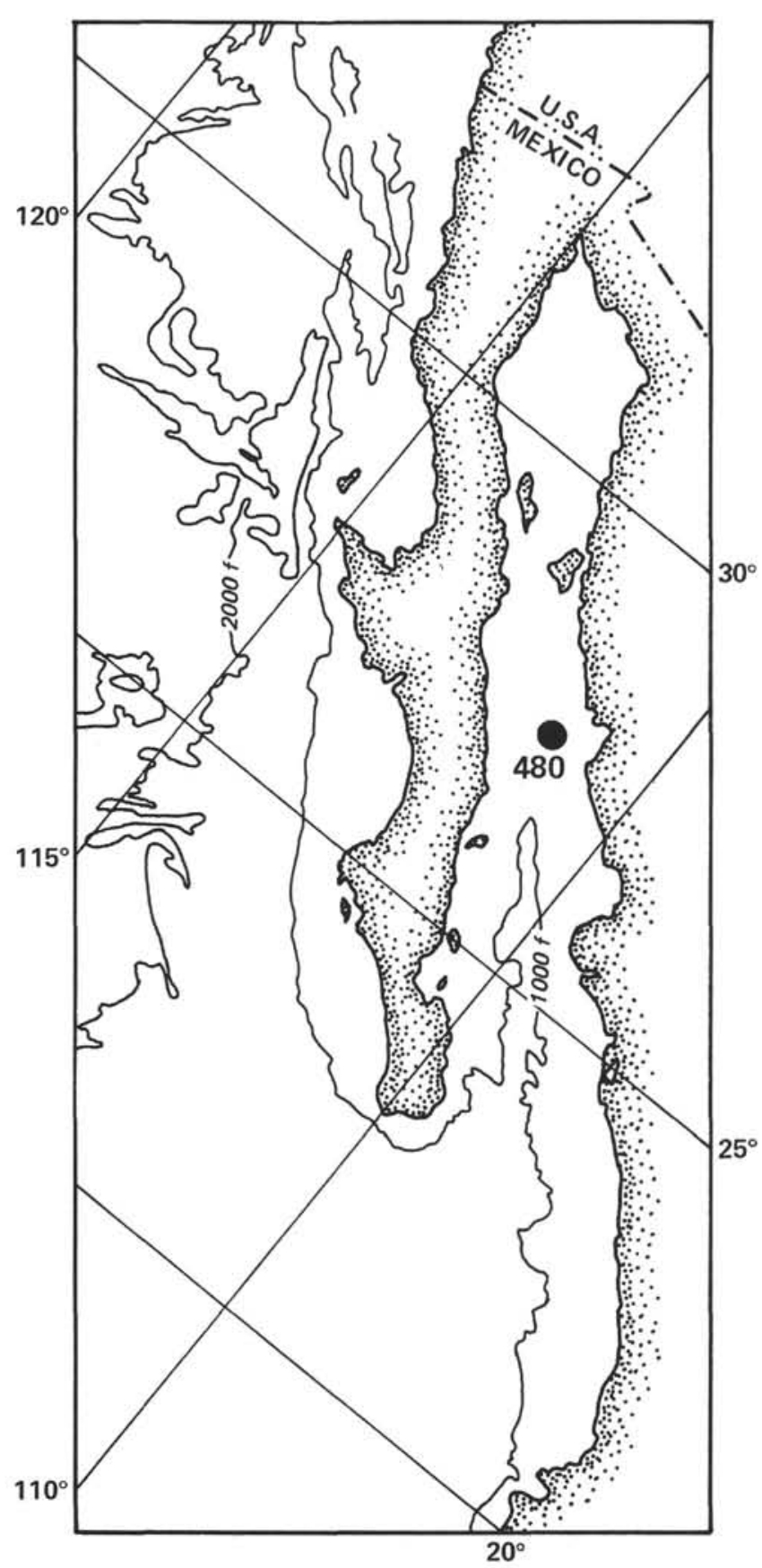

Figure 1. Site $480\left(27^{\circ} 54^{\prime} \mathrm{N}\right.$ latitude, $111^{\circ} 40^{\prime} \mathrm{W}$ longitude, $665-\mathrm{m}$ depth) in the central Gulf of California, Guaymas Basin. Depth contours are in fathoms.

\section{MODERN POLLEN RAIN}

The vegetation zones of the northern area of the Gulf of California are reflected in modern aerial and alluvial pollen records. In the Sonoran Desert, communities can be distinguished from woodland and forest communities by the predominance of nonarboreal pollen, primarily composites (representatives of the Compositae family), chenopods (members of the Chenopodiaceae and Amaranthus), and grasses (Gramineae) (Hevly et al., 1965). Percentage differences of chenopod and composite pollen, forming 25 to $50 \%$ of the pollen rain at low elevations, probably reflect local edaphic and climatic conditions (Hevly and Martin, 1961; Hevly et al., 1965; Solomon and Hayes, 1972). Chenopods correlate with summer rainfall and ragweed-type pollen (Ambrosia) correlates with winter moisture. Unfortunately, most plants that might separate communities within the desert are entomophilous and produce limited amounts of pollen (Hevly et al., 1965).

Grass pollen increases upslope, contributing up to $30 \%$ of the pollen rain at 1000 to 1700 meters (Hevly et al., 1965). At higher elevations, sagebrush (Artemisia), pine, and oak pollen, varying from $10 \%$ in the Sonoran Desert to 20 to $40 \%$ in samples from the Mojave Desert, occur in atmospheric and alluvial samples (Hevly et al., 1965; Leopold, 1967). Variations in the relative amount of exotic upland pollen in desert samples have been related to differences in the density of desert vegetation and to differences in the production of pollen (Hevly et al., 1965; Solomon and Hayes, 1972). According to Sirkin (1977), tropical vegetation zones, such as lowland and upland (mainly pine and oak) forests and mangrove, can be characterized by differences in pollen assemblages.

Pollen in the Gulf of California, as in other marine environments, is largely from fluvial sources (Cross et al., 1966). In Gulf sediments from about $21^{\circ} \mathrm{N}$ to $28^{\circ} \mathrm{N}$, arboreal pollen consists primarily of pine and oak from upland forests. Nonarboreal pollen comprises the principal desert types (composites and chenopods), and minor amounts of grass from the mesquite grasslands. Rare grains of Bursera and Simmondsia represent the entomophilous vegetation. Pollen is abundant in the Gulf, reaching up to 80,000 grains per gram of dry sediment (Cross et al., 1966). Pollen concentration in samples from a transect near Guaymas Basin was about 20,000 to 50,000 per gram, with pine contributing about 5000 grains per gram and oak contributing about 1000 to 2000 per gram. In the same transect, dinoflagellate concentration ranged from about 100 to 3000 cysts per gram. Microforaminifers, another palynomorph common in marine preparations, were not indicated in the northern transects; their distribution in the southern part of the Gulf of California corresponds with areas of upwelling (Cross et al., 1966).

\section{METHODS}

Dr. Kerry Kelts described the entire 152 meters of cores from Hole 480 in 10-centimeter intervals and removed about 10 to 15 cubic centimeters of sediment from the length of each interval. We processed 87 samples, equidistantly spaced throughout the cores, for pollen. Measured samples were suspended in sodium pyrophosphate and screened through a $150-\mu \mathrm{m}$ mesh. Coarse fractions were then sent to N. J. Shackleton for ${ }^{18} \mathrm{O}$ analysis. We treated fine fractions with sodium pyrophosphate and then with standard chemical procedures with $\mathrm{HCl}$, $\mathrm{HF}$, and acetolysis, followed by mild oxidation and screening through a $7-\mu \mathrm{m}$ mesh (Heusser and Shackleton, 1979). We mounted measured stained residues in glycerin-gelatin. The bulk of the samples taken by Dr. Kelts from Hole 480 were sent directly to N. J. Shackleton, who suspended the sediment in distilled water, screened off the coarse fraction $(>150 \mu \mathrm{m})$, and sent the fine fractions to L. Heusser for pollen preparation as previously described. Pollen and spores, identified with a regional reference collection, were counted until 300 pollen grains were tallied. We tabulated spores, dinoflagellates, microforaminifers, and reworked palynomorphs outside the basic pollen sum. 


\section{RESULTS}

Illustrated in Figure 2 are the major components of the pollen data from 100 samples taken at more-or-less equidistant intervals in the 152 meters of sediment from Hole 480 . Detailed pollen data from 70 samples taken at 10-cm intervals over 9 meters (480-3-1 through 480-4-3) are shown in Figure 3.

Pollen is moderately abundant in sediments from Cores 1 through 31 . Concentration ranges from 100 to 30,000 pollen grains $/ \mathrm{cm}^{3}$ of wet sediment-a crude, first-estimate figure, highly dependent on variations in the type of sediment and rate of deposition. The largest amounts of pollen are in homogeneous sediments (Sections 480-4-2; 480-4-3; 480-4-4); the lowest amounts are in laminated couplets, in diatomaceous ooze (Sections $480-1-1 ; 480-1-2 ; 480-1-3)$, and in disturbed homogeneous layers with coarse-grained components (Section 480-17-1).
Over half of the pollen in each of the 100 samples illustrated in Figure 2 is nonarboreal. Compositae (shortspined or Ambrosia-type) is generally the most abundant, followed by Artemisia-types (and long-spined types), Chenopodiaceae (including Amaranthus), and Gramineae. Less abundant herb and shrub pollen in Cores 1 through 31 are Ephedra, Larrea, Bursera, Beleperone, Simmondsia, Oenothera, and members of the Rosaceae, Rhamnaceae, Anacardiaceae, Cyperaceae, Umbelliferae, and Cactaceae. The arboreal pollen consists mostly of pine and oak derived from the 39 species of Pinus and 112 species of Quercus that occur in the Gulf of California. Minor percentages of Picea, Abies, Alnus, Salix, and Cupressaceae pollen are also present.

Vascular plant spores from the Polypodiaceae and Selaginellaceae are usually present but never abundant. Algal colonies (such as Pediastrum) and fungal spores also occur occasionally. Charred plant particles occur in varying quantities in samples from Cores 1 through 31 .

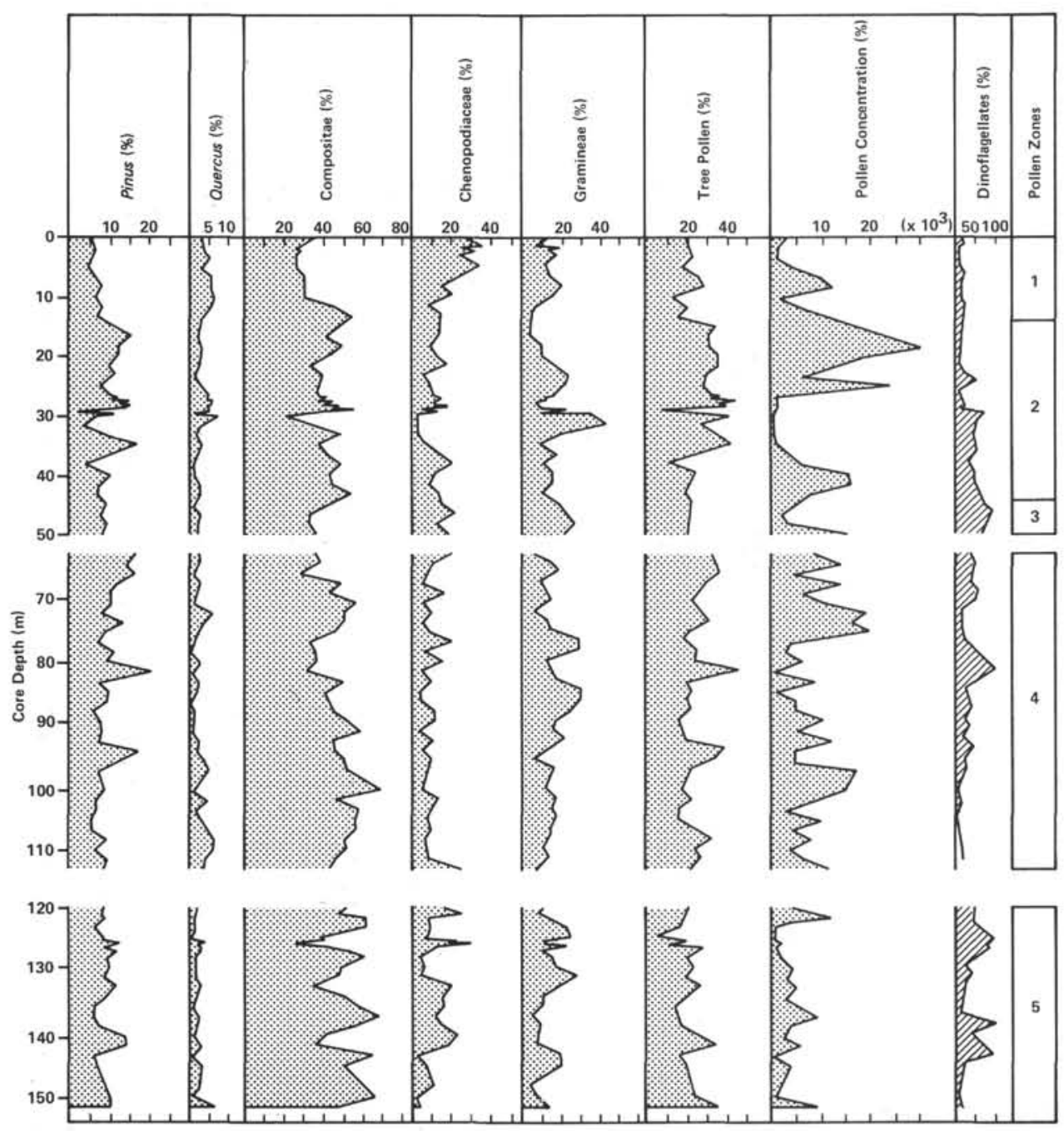

Figure 2. Relative abundance of selected pollen components from Hole 480. Pollen concentration (pollen grains $/ \mathrm{cm}^{3}$ wet sediment) and dinoflagellate abundance are shown on the right. 


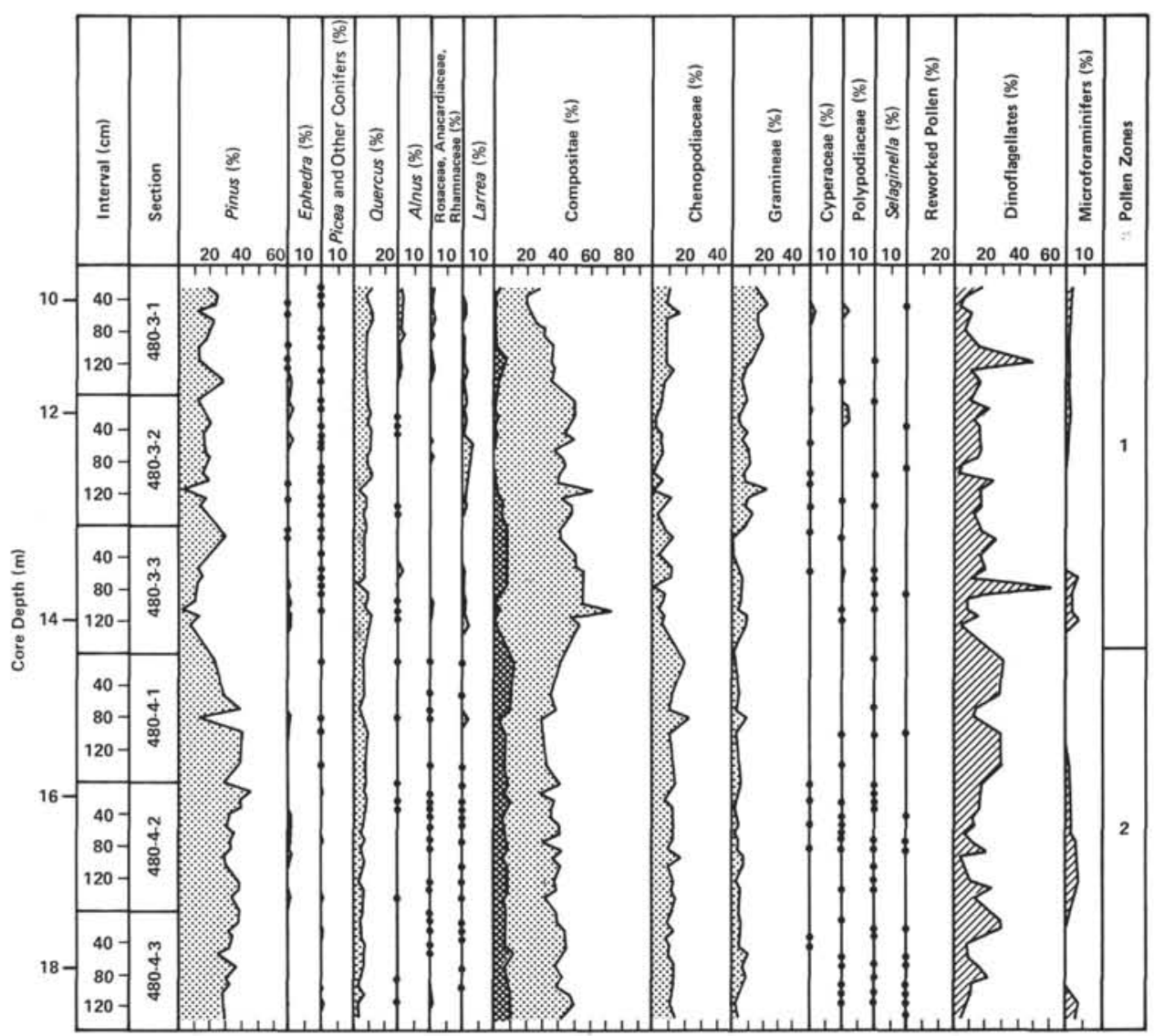

Figure 3. Relative abundance of the principal pollen and spore types in Core 3 Section 1 through Core 4 Section 3. Cross-hatching shows the relative frequencies of Artemisia in the Compositae. Percentages of other palynomorphs, reworked pollen, dinoflagellates, and microforaminifers are also indicated.

Dinoflagellate cysts are always present and range from 1- to $90 \%$ of the total palynomorphs. Tuberculodinium species periodically appear, and in the younger samples they are present in Sections 480-1-1 through 480-3-1 and absent in Sections 480-4-1 through 480-9-3.

For ease of discussion, this initial pollen diagram from Site 480 is provisionally divided into five pollen zones. ${ }^{2}$ The local or site zones (Birks and Berglund, 1979) are numbered from the top down. In Zone 1, the Chenopodiaceae zone, cheno-am pollen rises to maximum quantities $(25-35 \%)$ for all of the samples illustrated in Figure 2. In only one sample outside Zone 1 (Sample 480-26-1, 130-140 cm) are percentages of chenopods greater than $25 \%$. Grass also gradually increases upward from the base of this zone, rising to a peak in Section 480-2-3 and again in Section 480-1-2. The composite curve exhibits the longest sustained minimum of the pollen diagram, remaining at about $32 \%$ in Section 480 1-2 through Section 480-3-1. At the base of Zone 1, oak percentages double to $10 \%$ and then decrease from Section 480-2-3 upward. Larrea appears consistently, and dinoflagellates and microforaminifers are infrequent.

\footnotetext{
2 In view of the considerable time estimated to have taken place during the deposition of Cores 1 through 31 , we will further subdivide the diagram when additional pollen data are available.
}

Zone 2, the Compositae-Pinus zone, extends from Section 480-3-3 through Section 480-10-1 and is characterized by the prominence of Compositae and high percentages of arboreal types, mostly pine. In only one sample in this zone are composite percentages less than $35 \%$. This sample from Section 480-7-1 and another from Section 480-7-2 mark a brief interval of grass prominence in the pollen zone where composites predominate. Chenopods, relatively unimportant, decline to minimal percentages in the high grass interval. From the base of the zone, pine percentages rise to $35 \%$, decrease, and then rise to sustained high values of about $20 \%$ in the younger part of Zone 2 . Oak values rise in midzone and then remain at $5 \%$. Minor amounts of spruce and fir occur in each sample. Pollen concentration varies by a factor of 10 in Zone 2. Dinoflagellate trends are less oscillatory, decreasing gradually from $50 \%$ at the bottom of the zone to values comparable to those of Zone 1 at the top.

In the laminated sediments of the Gramineae-Chenopodiaceae zone (Zone 3), grass and chenopod percentages are similar to those found at the beginning of Zone 1; percentages of Compositae, pine, and oak pollen are lower than in Zone 2. Dinoflagellates are numerous -65 to $85 \%$ of all palynomorphs in Zone 3.

The Compositae zone (Zone 4) occurs in a long interval from about 60 to 115 meters of predominant com- 
posites, punctuated by a midzone rise of grass, three intervals of pine increase $(480-19-3 ; 480-17-1 ; 480-15-3$ to 480-13-1), and minimal amounts of oak and chenopods. Overall trends in this zone are a rise in composites from $20 \%$ at the base of the zone to a maximum of $75 \%$ in Section 480-21-2, followed by a steady decrease, a gradual increase of grass to midzone (480-17-2), a brief oscillation, and then a downtrend from Section 480-16-1 to $480-13-1$. Chenopods decrease from $25 \%$ in the basal sample of Zone 4 to about $10 \%$ in the remaining samples-except for those from Sections 480-16-1 and 480-13-1, where chenopods form $19 \%$ of the pollen sum. Spruce grains are present in almost all of the samples in Zone 4 . Less than $50 \%$ of the palynomorphs are dinoflagellates, exclusive of samples from Sections 480-16-3 and 480-17-1.

Basal Zone 5, a Compositae-Chenopodiaceae zone, is distinguished by oscillating frequencies of composites, chenopods, and grass. At least four cycles of succeeding dominance of grass, composites, and then chenopods occur. In four of the samples, chenopod percentages rise to $25 \%$-values similar to those of the upper part of Zone 1. From the basal samples in Zone 4, pine increases briefly $(480-29-2 ; 480-29-3)$ and then decreases gradually to the top of the zone. Oak remains essentially stable and unimportant. Pollen concentration is low in the laminated samples and rises to greater than 10,000 pollen grains $/ \mathrm{cm}^{3}$ in the one sample of homogeneous sediments $(480-25-2,30-39 \mathrm{~cm})$. Two intervals of dinoflagellate increase occur in Zone 5 (480-25-1; 480-25-2; 480-25-3; and 480-29-1; 480-30-1).

Detailed analyses of Section 480-3-1 through 480-4-3 (Fig. 3) show no major deviations from the trends of the profiles in Figure 2. The transitions between the more widely spaced data-points in the profiles of Figure 2 appear to be gradual. In the transition from the laminated sequence of Section 480-3-3 to the homogeneous sediments of Section 480-4-1, no abrupt change is indicated by the pollen data. Minor differences in the trends of some of the less frequently occurring palynomorphs in Zones 1 and 2 are suggested. Spruce and other conifers are sporadically present in Zone 1 and appear consistently in Zone 2, although never greater than $2 \%$. Alnus and Larrea are slightly better represented in Zone 1 than in Zone 2, whereas for Artemisia the situation is reversed. We saw no difference in the relative amount of microforaminifers in the diatomaceous ooze and homogeneous sediments. Except for two points in Zone 1, no apparent difference occurs in dinoflagellate abundance in the two zones.

\section{DISCUSSION}

Pollen concentration in sediments from the Guaymas Basin compares with that in the anoxic sediments of the Santa Barbara Basin, with the maximum concentration in sediments from the upper slope and rise of the northeast Pacific Ocean, and with concentration in sediments on the floor of the Mojave Desert (Heusser, 1978, Heusser and Balsam, 1977; Leopold, 1967). Although the quantity of pollen grains (tens of thousands) is at least an order of magnitude less than in temperate lakes and bogs, it is sufficient to provide meaningful data.
Pollen analysis of the sediments in the Guaymas Basin is facilitated by the small amounts of other palynomorphs in the residue. Redeposited grains, which can account for over $50 \%$ of palynomorphs in marine sediments derived from highly polleniferous rocks, are rare in this area dominated by volcanics (van Andel, 1964). Charcoal, which can also dilute the relative amounts of pollen in arid, fire-prone regions, is present but relatively uncommon. Dinoflagellate cysts can, when highly abundant (as in Zone 5), decrease the relative frequency of pollen; but the large quantity of raw sample available from the hydraulic piston corer enables us to obtain sufficient pollen for analysis. No clear relation between dinoflagellate abundance and sediment type was noticed. Although dinoflagellate abundance frequently has been linked with nutrient input and upwelling, there does not seem to be an apparent relation between the laminated sediments attributed to upwelling and dinoflagellate abundance in Hole 480.

Pollen composition and concentration in the laminated sediments of Site 480 are similar to the composition of surficial sediments from the Mojave and Sonoran deserts (Leopold, 1967; Hevly et al., 1965). The nonarboreal predominance of chenopods and composites, minor percentages of such diagnostic types as Bursera and Simmondsia, and small amounts of anemophilous types (pine and oak) from upland woodland communities characterize modern desert and Guaymas Basin sediments (Cross et al., 1966).

The similarity of pollen data from the surficial sediments of Site 480 to data from the arid, temperate vegetation of the Sonoran and other desert environments in the southwestern United States suggests that the primary source of pollen in the sediments of Guaymas Basin is the desert vegetation of the Sonoran province. The wide distribution of desert vegetation around the Gulf of California and the Río Yaqui, the principal source of terrestrial sediment in Guaymas Basin, accounts for much of the similarity in the marine and terrestrial pollen spectra (van Andel, 1964; Cross et al., 1966). The similarity of the surficial marine and continental spectra is related to the proximity of the Basin to shore and to the anoxic nature of the sediments in the Guaymas Basin. The differential effects of transport and the destructive oxidation of pollen grains are less than in marine environments farther offshore (Cross et al., 1966; Heusser and Balsam, 1977).

Pollen from other sources is probably also present in the Guaymas Basin. Some aeolian input of temperate vegetation and perhaps of tropical vegetation from the south occurs. As the Río Yaqui flows from the Sierra Madre Occidental, pollen derived from the altitudinally differentiated vegetation zones is transported to the Basin. Minor amounts of upland pollen were described in other parts of the Gulf and in other marine cores (Cross et al., 1966; Heusser, 1978; Muller, 1959).

Comparing the fossil marine pollen with modern spectra from the adjacent continent indicates that analogues of the marine spectra can be approximated by the modern records of existing plant communities in the Sonora and Mojave deserts (Hevly and Martin, 1961; Leopold, 1967; Martin, 1964). The preponderance of 
nonarboreal pollen at the top of the sedimentary column of Hole 480 (and which continues downcore), indicates that desert vegetation was present and predominant in the source area of Guaymas Basin when the 152 meters of sediment were deposited. Although it is possible that very different pollen and inferred vegetation may have been present during intervals not sampled, the detailed analyses of Sections 480-3-1 through 480-4-3 (Fig. 3) show no large deviations from the pollen profiles of the more widely spaced analyses (Fig. 2). Early speculations about the nature of the Sonoran Desert during the "pluvial" environment of the last glacial suggested that expanded grasslands and upland vegetation would have limited desert vegetation to small refugia. Subsequent microfossil and macrofossil data indicate that, during the last Wisconsinan and early Holocene, desert species similar to those of the present were widely distributed (Martin and Mehringer, 1965; van Devender and Spaulding, 1979). Pollen data from Site 480 extend the history of the Sonoran Desert, confirming the widespread existence of desert vegetation during the last glacial and presumably during the last interglacial and penultimate glaciation-the period encompassed by Cores 480-1 through 480-31.

Oscillations in the composite, chenopod, and grass curves (Fig. 2) indicate major changes in the distribution or composition of desert plants and communities (van Devender and Spaulding, 1979). An extended interval of chenopod expansion (Zone 1), presumably reflecting wide distribution of saltbush scrub and alkaline flat communities, does not seem to have occurred in the earlier part of the Hole 480 pollen record. There is a suggestion that the chenopod rise in Zones 3 and 5 (especially near $125 \mathrm{~m}$ ) may represent a similar assemblage and inferred environment and that the apparent difference in duration may be related to differences in sedimentation and compaction. It is also possible that assemblages similar to those in Zone 1 were deposited during intervals not analyzed: They lie between the sample intervals or occur in intervals not sampled in the coring. Another less probable alternative is that if, as Schrader (this volume Pt. 2) suggests, the cores from Hole 480 penetrate one or two earlier interglacials, then the pollen and vegetation assemblages of these previous interglacials were unlike those of the present desert environments.

Most of the nonarboreal pollen record is predominantly composites and grass, suggesting expanded creosote bush scrub, chaparral, savannah, and mesquite grassland. Zones 2,4 , and 5 are also characterized by the highest amounts of arboreal pollen derived from upland woodlands and forests. In the Sonoran Desert, other arid environments of the southwestern United States, and in tropical Mexico, such increases in the relative amount of pine have been interpreted as indicating a local increase in woodland and forest due to a climatically induced elevational depression of the vegetation zones (Clisby and Sears, 1956; Leopold, 1967; Martin, 1963; Sirkin, 1977). Percentages of pine and other arboreal pollen in desert environments may also reflect the density of the local desert plant cover (Martin,
1963); thus, the relative amount of pine may be an inverse measure of local desert pollen and vegetation (Solomon, 1976).

Although the precise meaning of local changes in arboreal pollen percentages from desert alluvium may be equivocal, changes in the pollen content in the Guaymas Basin reflect regional changes. Differences in the relative amount and concentration of arboreal pollen, such as those in Zones 1 and 2, seem to reflect regional differences in the contribution of pollen from woodland communities during those intervals. The increased amount of pine in the upper half of Zone 2 seems to reflect increased pine pollen production resulting from pine woodland expansion in the source area of the Guaymas Basin pollen. The pine was accompanied by expanded grass and later by increased composites, such as those derived from creosote bush and chaparral. At the base of Zone 1, characterized by less pine and inferred pine woodland, a brief expansion of oak scrub, saltbush scrub, and alkaline flat communities is inferred from the rise in oak and chenopod pollen.

Pollen data from Site 480 appear to be consistent with regional fossil pollen data and with regional vegetational reconstructions, indicating that, prior to the present interglacial, deserts were occupied by vegetation now found at higher elevations (van Devender and Spaulding, 1979; Martin, 1963; Martin and Mehringer, 1965). In Zones 2 and 3 in Hole 480, the trend of the major components is similar to that from a 42 -meter core from the Sonoran Desert of southern Arizona (Martin, 1963). Profiles from the upper 28 meters of Hole 480 are tentatively correlated with events from the end of the last glacial and the present interglacial. The upper part of Zone 2 may correspond with the interval of expanded chaparral and pine woodland in the late Wisconsinan that ended about 10,000 years ago (van Devender and Spaulding, 1979). The rise of oak in Zone 1 might correlate with the early Holocene interval about 10,000 to 8000 years ago when middle elevation oak woodlands increased and pine diminished (van Devender and Spaulding, 1979). The upper eight meters of sediments from Hole 480 seems to correspond with the development of modern desert vegetation.

Climatic interpretation of the pollen data from Site 480 is hindered by the incomplete understanding of the present interrelations between pollen, vegetation, and climatic parameters in the Sonoran Desert. The distribution of plant communities is directly related to soil salinity, water availability, and temperature (Burk, 1977; Leopold, 1950). Rainfall appears to be the overriding factor in water stress in the Sonoran Desert, and Solomon and Hayes (1972) found strong positive correlations between winter rainfall and chenopod pollen and between summer rainfall and composite pollen. Thus, the chenopod curve in Figure 2 would indicate winter precipitation, and high chenopod percentages would indicate high winter rainfall as, for example, in the upper part of Zone 1, The high composite percentages of Zone 2 would then indicate high summer rainfall. If the chronological correlation of the pollen data from Site 480 with van Devender and Spauldings' data 
is correct, during the intervals just referred to, precipitation estimates based on macrofossil data indicate the opposite: That is, van Devender and Spaulding (1979) suggest that modern deserts are related to decreased winter precipitation and that full glacial vegetation (20,000-10,000 years ago) was characterized by increased winter precipitation in the southwestern United States. The resolution of this apparent discrepancy depends on establishing the chronology of Hole 480 and understanding the relation between macrofossil and microfossil data from desert environments.

\section{CONCLUSION}

These initial pollen data from Site 480 indicate the potential for developing a long, detailed record of vegetation environments adjacent to the Gulf of California. By using various techniques, ranging from increasing the counts of diagnostic but little-represented pollen types and other palynomorphs (Nichols, 1975) to multivariate analysis of present and past pollen influx data, we can develop a sensitive record of climatic change in a little-known region.

\section{ACKNOWLEDGMENTS}

The author gratefully acknowledges the support of NSF grant DEB 79-12231 and the comments of the reviewers, L. Sirkin and C. Heusser.

\section{REFERENCES}

Birks, H. J. B., and Berglund, B. E., 1979. Hoiocene pollen stratigraphy of southern Sweden: a reappraisal using numerical methods. Boreas, 8:257-279.

Burk, J., 1977. Sonoran desert. In Barbour, M. G., and Major, J. (Eds.), Terrestrial Vegetation of California: New York (John Wiley), 869-891.

Calvert, S. E., 1964. Factors affecting distribution of laminated diatomaceous sediments in the Gulf of California. In van Andel, Tj. H., and Shor, G. G. (Eds.), Marine Geology of the Gulf of California, Mem.-Am. Assoc. Pet. Geol., 3: Tulsa (American Association of Petroleum Geologists), 311-330.

Clisby, K. H., and Sears, P. B., 1956. San Augustin Plains-Pleistocene climatic changes. Science, 124:537-539.

Cross, A. T., Thompson, G. G., and Zaitzeff, J. B., 1966. Source and distribution of palynomorphs in bottom sediments, southern part of Gulf of California. Mar. Geol., 4:467-524.

Hastings, J. R., Turner, R. M., and Warren, D. K., 1972. An Atlas of Some Plant Distributions in the Sonoran Desert. Metero. Climatol. Arid Regions Tech. Rept. 21: Tucson (University of Arizona Institute of Atmospheric Physics).

Heusser, L., 1978. Pollen in Santa Barbara Basin, California: a 12,000yr record. Geol. Soc. Am. Bull., 89:673-678.
Heusser, L. E., and Balsam, W. L., 1977. Pollen distribution in the northeast Pacific Ocean. Quat. Res., 7:45-62.

Heusser, L. E., and Shackleton, N. J., 1979. Direct marine-continental correlation: 150,000-year oxygen isotope-pollen record from the North Pacific. Science, 204:837-839.

Hevly, R. H., and Martin, P. S., 1961. Geochronology of pluvial Lake Cochise, southern Arizona: I. pollen analysis of shore deposits. J. Ariz. Acad. Sci., 2:24-31.

Hevly, R. H., Mehringer, P. J., and Yocum, H. G., 1965. Modern pollen rain in the Sonoran Desert. J. Ariz. Acad. Sci., 3:123-135.

Leopold, A. S., 1950. Vegetation zones of Mexico. Ecology, 31:507517.

Leopold, E. B., 1967. Summary of palynological data from Searles Lake. Pleistocene Geology and Palynology of Searles Valley, California. Friends of the Pleistocene, Pacific Coast Section: 52-66.

Martin, P. S., 1963. The Last 10,000 Years: Tucscon (University of Arizona Press).

, 1964. Pollen analysis and the full-glacial landscape. In Hester, J. J., and Schoenwetter, J. (Eds.), Reconstruction of Past Environments: Taos, NM (Fort Burgwin Research Center), 66-74.

Martin, P. S., and Mehringer, P. J., 1965. Pleistocene pollen analysis and biogeography of the southwest. In Wright, H. E., and Frey, D. G. (Eds.), The Quaternary of the United States. Princeton: (Princeton University Press), 433-452.

Muller, J., 1959. Palynology of recent Orinoco delta and shelf sediments. Micropaleontology, 5:1-32.

Nichols, H., 1975. Palynological Studies of the Holocene Displacements of Forest-Tundra Ecotone in Keewatin and Mackenzie, N.W.T., Canada. University of Colorado Institute of Arctic and Alpine Research Occasional Paper 15.

Roden, G. I., 1964. Oceanographic aspects of Gulf of California. In van Andel, Tj. H., and Shor, G. G. (Eds.), Marine Geology of the Gulf of California, Mem.-Amer. Assoc. Pet. Geol. 3: Tulsa (American Association of Petroleum Geologists), 30-58.

Sirkin, L., 1977. Late Pleistocene palynology and stratigraphy of the west Mexican coastal plain. X INQUA Congress, Birmingham. (Abstract)

Solomon, A. M., 1976. Pollen analysis of alluvial sediments: implications of experimental evidence from sedimentary and atmospheric pollen samples. Fourth Biennial Mtg. American Quaternary Asso., Tempe, Arizona. (Abstract)

Solomon, A. M., and Hayes, H. D., 1972. Desert pollen production I: qualitative influence of moisture. J. Ariz. Acad. Sci., 7:52-74.

Soutar, A., 1971. Micropaleontology of anaerobic sediments and the California current. In Funnel, B. M., and Riedel, W. R. (Eds.), The Micropaleontology of Oceans: London (Cambridge University Press), 223-230.

van Andel, Tj. H., 1964. Recent marine sediments of the Gulf of California. In van Andel, Tj. H., and Shor, G. G. (Eds.), Marine Geology of the Gulf of California, Mem.-Amer. Assoc. Pet. Geol. 3: Tulsa (American Association of Petroleum Geologists), 216-310.

van Andel, Tj. H., and Shor, G. G., 1964. Marine Geology of the Gulf of California, Mem.-Amer. Assoc. Pet. Geol. 3: Tulsa (American Association of Petroleum Geologists).

van Devender, T. R., and Spaulding, W. G., 1979. Development of vegetation and climate in the southwest United States. Science, 204:701-710. 